Audiology

\title{
Effect of loading of the central part of the tympanic membrane on pure tone audiometry
}

\author{
Applicazione di pesi a livello della parte centrale della membrana timpanica: \\ effetti sull'audiometria tonale
}

\author{
M.K.T.M. ABDALLA1', M.A. BASSIONY', M.T. AZIZ1', Y.G. SHEWEL \\ ${ }^{1}$ Department of Otorhinolaryngology, Head and Neck Surgery, Alexandria University, Alexandria, Egypt
}

\section{SUMMARY}

This study was conducted to determine the effects of loading of the central part of the tympanic membrane by different weights on pure tone audiometry of healthy ears. Sixty patients with normal otoscopic view, normal pure tone audiometry and wide external auditory canal to allow direct and endoscopic visualization of TM, but without any history of ear surgeries, were selected and divided equally and randomly into two groups. Loading of the central part of the TM was carried out using weights ranging from [(1 $\lambda) 13.6 \mathrm{mg}]$ to [(40 $\lambda) 544 \mathrm{mg}]$; $(\lambda)$ is a symbol for the weight of 1 microliter of mercury. The study was carried out in two steps assisted by direct oto-endoscopy, and pure tone audiometry was used to measure the effects of loading on both air and bone conduction hearing. Air conduction hearing thresholds increased in a statistically significant pattern at low frequencies, $500 \mathrm{~Hz}, 1000 \mathrm{~Hz}$ and $2000 \mathrm{~Hz}$, when the TM was loaded by $340 \mathrm{mg}(25 \lambda)$. The maximal effect was recorded at $544 \mathrm{mg}(40 \lambda)$, which affected air conduction hearing at all tested frequencies $(500 \mathrm{~Hz}, 1000 \mathrm{~Hz}$, $2000 \mathrm{~Hz}$ and $4000 \mathrm{~Hz}$ ). However, no statistically significant effect was detected on bone conduction hearing thresholds throughout the study. In conclusion, loading of the tympanic membrane by different masses affects the air conduction hearing threshold by only 340 mg $(25 \lambda)$, which is very large in comparison to the mass of ossicles, without any significant effects on bone conduction hearing.

KEY WORDS: Loading • The central part of the Tympanic Membrane $\bullet$ Compressed aluminum pellets $\bullet$ Pure tone audiometry $\bullet$ Hearing threshold

\section{RIASSUNTO}

Questo studio è stato condotto al fine di determinare gli effetti sull'audiometria tonale dell'applicazione di masse di peso differente a livello della porzione centrale della membrana timpanica di un orecchio sano. Sono stati selezionati sessanta pazienti con anamnesi negativa per pregressa chirurgia dell'orecchio, aventi otoscopia nella norma, soglia audiometrica tonale nella norma, e un canale uditivo esterno sufficientemente ampio da permettere la visione endoscopica diretta della membrana timpanica. I pazienti sono stati equamente suddivisi in maniera randomizzata in due gruppi, Gruppo I e Gruppo II. Sono state utilizzate masse di differente peso, da 13,6 mg (1 $\lambda$ ) a $544 \mathrm{mg}(40 \lambda)$; $\lambda$ è pari al peso di un microlitro di mercurio. Lo studio è stato condotto in due steps, sotto visione otoendoscopica; l'audiometria tonale è stata utilizzata per valutare l'effetto dell'applicazioni dei pesi, sia sulla via aerea sia sulla via ossea. Con l'applicazione di un peso pari a $340 \mathrm{mg}(25 \lambda)$, la soglia per via aerea è aumentata in maniera statisticamente significativa alle frequenze di $500,1000 \mathrm{e} 2000 \mathrm{~Hz}$. Il massimo risultato è stato ottenuto con un peso pari a $544 \mathrm{mg}(40 \lambda)$, che ha avuto effetto su tutte le frequenze testate $(500,1000,2000 \mathrm{e} 4000 \mathrm{~Hz})$. Tuttavia, non è stato registrato alcun effetto statisticamente significativo sulla conduzione per via ossea. In conclusione, l'applicazione di pesi a livello della membrana timpanica, utilizzando però masse di peso notevole (340 mg), modifica la conduzione e la soglia per via aerea, ma non ha alcun effetto statisticamente significativo sulla conduzione per via ossea.

PAROLE CHIAVE: Porzione centrale della membrane timpanica $\bullet$ Audiometria tonale $\bullet$ Soglia audiometrica

Acta Otorhinolaryngol Ital 2018;38:229-235

\section{Introduction}

Despite its clinical and surgical importance, mass loading of the central part of the tympanic membrane (TM), particularly point wise version, is a rarely discussed topic in the literature.
Basically, a stroboscopic holographic interferometer, which is used to measure vibration of the human TM, reveals that when it is stimulated by $500 \mathrm{~Hz}$ and $1000 \mathrm{~Hz}$, its entire surface moves in points with the major indications occurring in posterior half. However, at 2000 and $4000 \mathrm{kHz}$, the TM vibrates with multiple (4 to 10) lo- 
cal maxima, dispersed throughout the surface of the TM. Many of these maxima occur at the same phase of stimulation, while some occur at the opposite phase, and others show signs of graded phase with position (maxima means the point of maximal vibration) ${ }^{12}$.

Vibrations of TM are affected by its mass; when it increases, volume velocity generated by the acoustic stimulus is expected to decrease ${ }^{3}$. Moreover, suppression of such vibration leads to variable degrees of hearing loss, if they are suppressed in a selective and focused way (pointwise), which will produce degrees of hearing loss that are essentially different from hearing loss produced from surface loading (covering), in turn inhibiting all TM vibration ${ }^{4}$. The main two studies in this field revealed that a $0.13 \mathrm{~cm}^{3}$ mercury drop, which weighs about $176 \mathrm{mg}$, causes a loss of almost 20 to $40 \mathrm{~dB}$, while a water drop of volume $0.2 \mathrm{~cm}^{3}$ produces a loss of only about $3-27 \mathrm{~dB}$, while oil occupies an intermediate position ${ }^{13}$; both studies investigated the surface covering effect. This means that mass loading on a specific part of the TM has not been tested on humans. In this study, the 'pointwise' method was used not only because it is not studied previously, but also because if the effect is known clearly it will provide practical, scientific and non-statistical evidence why heavy and light grafts such as cartilage and fascia respectively have similar hearing results as is well known in the current literature ${ }^{5}$.

\section{Materials and methods}

The study involved 60 patients who attended the outpatient clinic of the Otolaryngology-Head and Neck Surgery Department, Alexandria Main University Hospital seeking treatment for non-otological conditions. They were prospectively recruited to participate in the study which was approved and conducted by the guidelines of the local institutional review board. Moreover, all participants signed informed detailed consent prior to the study.

All participants had normal otoscopic view, normal pure tone audiometry and wide external auditory canal to allow direct and otoscopic visualization of the TM; they did not have any history of ear surgeries.

The 60 participants were divided randomly and equally in two groups, Group I and Group II, each with 30 participants.

The study was done in two steps:

The first step was a preliminary study to detect the load that might affect hearing; it was conducted for group ' $\mathrm{I}$ ' (60 TMs) according to the following steps:

1. Full audiological assessment of all participants in the form of air and bone conduction pure tone audiometer to make sure that they had normal air and bone conduction hearing thresholds, and imminence audiometer, including tympanometry and static imminence to ensure a normal middle ear condition.

2. Loading of the tympanic membrane:

I. Preparation of loads:

A)Weight of loads:

The basic weight was 13.6 and its multiples because Tonndorf, J. (1964) used a one microliter mercury drop, which weighs $13.6 \mathrm{mg}(\lambda)$, as the smallest load to measure the effect of mass loading in animals and five multiples of this weight to measure further effects ${ }^{6}$; it is also the weight of the tympanic membrane. Thus, this weight and 10 multiples were used to improve the accuracy of the results:

[(1 $\lambda) 13.6 \mathrm{mg}],[(2 \lambda) 27.2 \mathrm{mg}],[(5 \lambda) 68 \mathrm{mg}],[(10 \lambda)$

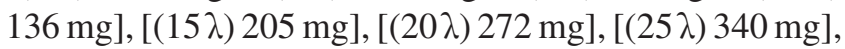
[ $(30 \lambda) 408 \mathrm{mg}],[(35 \lambda) 476 \mathrm{mg}]$ and $[(40 \lambda) 544 \mathrm{mg}]$

B) Shape and surface area:

Because it was extremely difficult to reach the heavy weights in a small surface area to ensure pointwise loading principle and all loads are expected to have standard measures, square shaped aluminum plates with a surface area of $16 \mathrm{~mm}^{2}$ (Fig. 1) were also used because it is the resting surface area of a mercury drop $\left(13 \pm 3.58 \mathrm{~mm}^{2}\right)$ used by prior researchers.

C) Composition of load:

We selected aluminum loads because it was easy to shape it and easy to reach the target weight with the standardised surface area. The smaller loads, up to $340 \mathrm{mg}$, were prepared from aluminum foil that was folded to give the

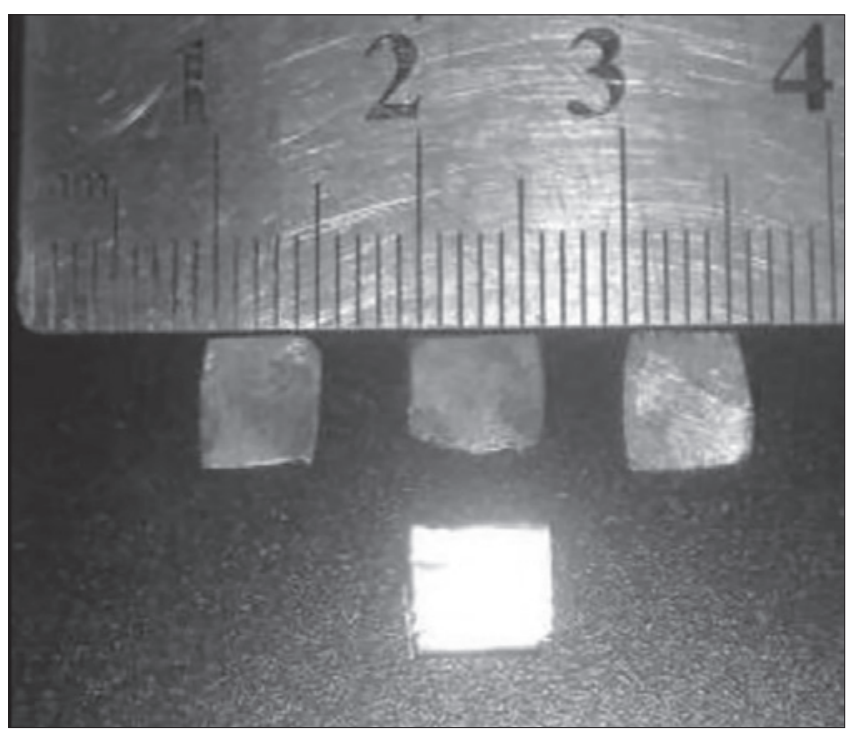

Fig. 1. Different weights with different thicknesses and surface area. 
target weight and surface area. However, the larger loads were prepared from thick aluminum pellets that were compressed to the standard measures because it was difficult to reach the target weight using the thin aluminum foil (Fig. 1).

D) Total loads: all 10 selected weights had six further loads each, for a total of 60 loads.

II. Application of loads:

Each ear in group I was loaded by one of the prepared loads as the following:

An otoendoscope of $2.0 \mathrm{~mm}$ diameter, $58 \mathrm{~mm}$ length and $0^{\circ}$ angles, was used to help good visualisation of all circumferences of the TM (umbo, malleus, annulus anterior and posterior malleolar folds), under this clear vision $0.05 \mathrm{ml}$ of greasy and high viscosity petroleum jelly was applied to the umbo to prevent fall of the load.

Then, a plate of unknown weight, for both the patient and audiologist, was adjusted to the TM at the region of the umbo without any contact with the walls of the external auditory canal (Fig. 2).

3) Audiological assessment.

This step was double-blinded as neither the audiologist nor patient had any information about the weight of the plates.

Pure tone audiometry was done immediately after application of the loads to assess the effect of each load on air and bone conduction hearing thresholds at frequencies of $(500 \mathrm{~Hz}, 1000 \mathrm{~Hz}, 2000 \mathrm{~Hz}$, and $4000 \mathrm{~Hz}$ ).

4) Plates were removed a few hours after they fell from the TM with oto-endoscopic assistance.

After the results of this stage had been calculated, the second stage was conducted to confirm them, and included the same steps but with some differences:

1. Five weights were selected from the weights of the first

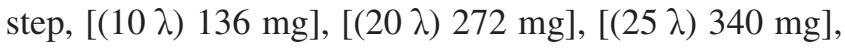
[(30 $\lambda) 408 \mathrm{mg}],[(40 \lambda) 544 \mathrm{~m}]$, to confirm positive and negative results of the first step.

2. Number of loads:

Twelve plates for each of the five selected weights were prepared; 60 loads of above mentioned measures and compositions were prepared. Each ear in group II was loaded by one of the prepared loads using the same method in the first step.

\section{Statistical analysis of loading effects}

At the beginning, we calculated the means and standard deviations of pre- and post-loading air and bone conduction hearing thresholds for each load at $500 \mathrm{~Hz}$, $1000 \mathrm{~Hz}, 2000 \mathrm{~Hz}$ and $4000 \mathrm{~Hz}$. Subsequently, the mean differences between pre- and post-loading means were calculated.

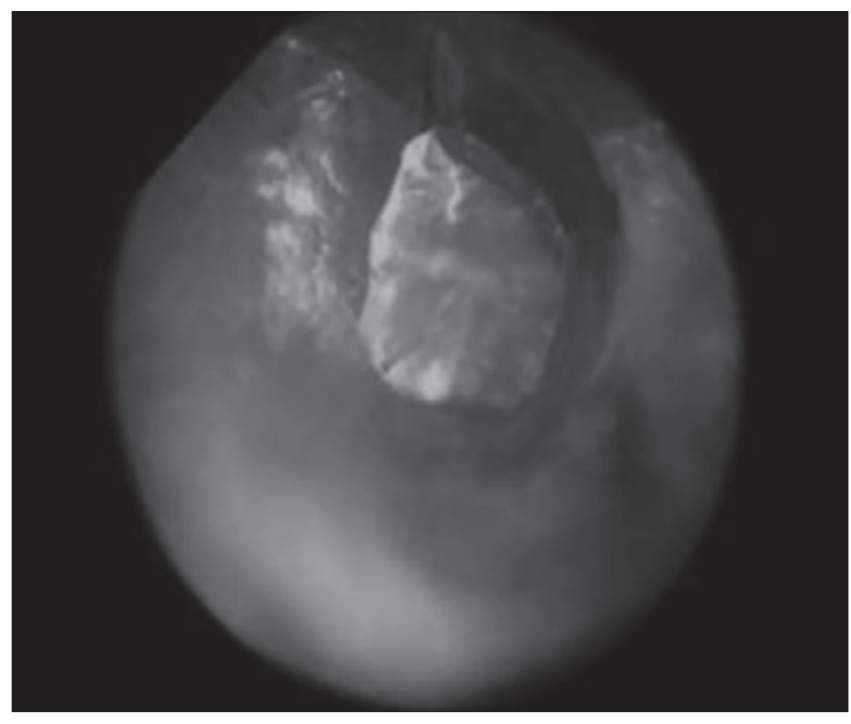

Fig. 2. The weight loaded on the TM.

After that, a t-test was used to compare the mean of the preloading air and bone conduction with post-loading counterparts for every load at $500 \mathrm{~Hz}, 1000 \mathrm{~Hz}, 2000 \mathrm{~Hz}$ and $4000 \mathrm{~Hz}$. A two-tailed p-value was used to measure the statistical significance of measured differences.

Lastly, 95\% confidence interval and standard error of difference was used to improve the accuracy of results for step two results.

\section{Results}

The study included 48 males and 12 females, with an age ranging from 20-58 years and a mean of $33.9 \pm 10.04$ years. The mean weight of the ointment pieces used to hold the plate in place was $3 \pm 0.58 \mathrm{mg}$ in vitro. This weight was neglected not only because it was impossible to measure the real weight of the ointment on the TM (in vivo) due to the wasted amount on the tip of the cotton applicator, but also because the same volume $(0.05 \mathrm{ml})$ was used in all cases.

\section{Results of the first step}

Small loads (13.6 mg, $27.2 \mathrm{mg}, 68 \mathrm{mg}, 136 \mathrm{mg}, 205 \mathrm{mg}$, and $272 \mathrm{mg}$ ) did not have any significant effect on either type of hearing. The two-tailed p-value was $\geq 0.05$.

A statistically significant effect of mass loading was detected when the TM was loaded by $340 \mathrm{mg}(25 \lambda)$. The mean air conduction hearing losses were $10 \pm 3.55 \mathrm{~dB}$, $10 \pm 2.35 \mathrm{~dB}$ and $10 \pm 3.69 \mathrm{~dB}$ at 500,1000 and $2000 \mathrm{~Hz}$, respectively, with a p-value $<0.05$. However, some differences were measured at $4000 \mathrm{~Hz}$, although these differences were not statistically significant. 
The effect increased gradually as the weight of the load was increased; at $476 \mathrm{mg}$ (35 $\lambda)$ the mean differences between the mean pre- and post-loading air conduction hearing thresholds were $-5 \pm 5.22 \mathrm{~dB},-10 \pm 3.98 \mathrm{~dB}$, $-15 \pm 4.22 \mathrm{~dB}$, and $-15 \pm 2.35 \mathrm{~dB}$ at $500 \mathrm{~Hz}, 1000 \mathrm{~Hz}$, $2000 \mathrm{~Hz}$, and $4000 \mathrm{~Hz}$, respectively, with a two-tailed pvalue $<0.05$.

Similarly, at the maximal weight used in this study, $544 \mathrm{mg}(40 \lambda)$, the mean air conduction hearing loss was $15 \pm 4.32 \mathrm{~dB}$ at $500 \mathrm{~Hz}$ and $10 \pm 3.47 \mathrm{~dB}, 10 \pm 4.29 \mathrm{~dB}$ and $10 \pm 3.22 \mathrm{~dB}$ at 1000,2000 and $4000 \mathrm{~Hz}$, respectively. Lastly, none of the loads had a statistically significant effect on bone conduction hearing thresholds.

\section{Results of the second step}

When the TM was loaded by $136 \mathrm{mg}(10 \lambda)$, the mean of differences between pre- and post-loading air hearing thresholds were $0 \pm 0.36 \mathrm{~dB}$ at $500 \mathrm{~Hz}, 1 \pm 0.58 \mathrm{~dB}$ at $1000 \mathrm{~Hz}, 0 \pm 0.98 \mathrm{~dB}$ at $2000 \mathrm{~Hz}$ and $1 \pm 1.36 \mathrm{~dB}$ at $4000 \mathrm{~Hz}$, with no significant differences. However, there were similar differences in bone conduction hearing thresholds $(2 \pm 0.25 \mathrm{~dB}$ at $500 \mathrm{~Hz}, 0 \pm 0.89 \mathrm{~dB}$ at $1000 \mathrm{~Hz}$, $1 \pm 1.89 \mathrm{~dB}$ at $2000 \mathrm{~Hz}$ and $1 \pm 0.36 \mathrm{~dB}$ at $4000 \mathrm{~Hz}$ ), none of which were statistically significant ( $p>0.05$ for all; Table I).

Similarly, at $272 \mathrm{mg}$, there were several differences at air and bone conduction hearing, but none with any statistical significance (Table II). Line graph of pre- and post-loading thresholds were identical without any gaps (Fig. 3). A statistically significant effect of mass loading was detected when the TM had a central load of $340 \mathrm{mg}(25 \lambda)$. At this weight, the mean differences at $500 \mathrm{~Hz}, 1000 \mathrm{~Hz}$ and $2000 \mathrm{~Hz}$ were statistically significant with paired p-value $<0.05$; at $500 \mathrm{~Hz}$ the mean difference was $-10 \pm 2.35 \mathrm{~dB}$, at $1000 \mathrm{~Hz}$ the ear lost $10 \pm 4.45 \mathrm{~dB}$ and at $2000 \mathrm{~Hz}$ air conduction hearing loss was $10 \pm 2.18 \mathrm{~dB}$. However, the effect of this mass was not significant at $4000 \mathrm{~Hz}$ (Table III) (Fig. 4), although with no statistically significant effect on bone conduction hearing (Table III).

At $408 \mathrm{mg}(30 \lambda)$, the mean air conduction hearing losses (mean differences) were $17 \pm 3.38 \mathrm{~dB}$ at $500 \mathrm{~Hz}$, $16 \pm 4.87 \mathrm{~dB}$ at $1000 \mathrm{~Hz}$ and $10 \pm 2.60 \mathrm{~dB}$ at $2000 \mathrm{~Hz}$. Nonetheless, this had no significant effect on $4000 \mathrm{~Hz}$ (Table IV). There were several differences in bone conduction hearing thresholds, but none with statistical significance ( $p>0.05$ for all; Table IV).

The above-mentioned effect increased in intensity when TM had a load of $544 \mathrm{mg}(40 \lambda)$. The mean air conduction hearing loss (mean difference) was $20 \pm 3.44 \mathrm{~dB}$ at $500 \mathrm{~Hz}$, which continued at other frequencies but to a lesser degree, $(14 \pm 5.67 \mathrm{~dB}$ at $1000 \mathrm{~Hz}, 10 \pm 3.58 \mathrm{~dB}$ at $2000 \mathrm{~Hz}$ and $10 \pm 3.98 \mathrm{~dB}$ at $4000 \mathrm{~Hz}$; Table V). Larger gaps between pre- and post-loading air conduction hearing threshold depicted this phenomenon (Fig. 5). Similar

Table I. Changes in hearing thresholds at $136 \mathrm{mg}$.

\begin{tabular}{|c|c|c|c|c|c|c|c|c|c|}
\hline \multirow{2}{*}{$\begin{array}{l}\text { Loads } \\
\text { Step } 2\end{array}$} & & \multicolumn{4}{|c|}{ Changes of air conduction hearing thresholds } & \multicolumn{4}{|c|}{ Changes of bone conduction hearing thresholds } \\
\hline & & $500 \mathrm{~Hz}$ & $1000 \mathrm{~Hz}$ & $2000 \mathrm{~Hz}$ & $4000 \mathrm{~Hz}$ & $500 \mathrm{~Hz}$ & $1000 \mathrm{~Hz}$ & $2000 \mathrm{~Hz}$ & $4000 \mathrm{~Hz}$ \\
\hline \multirow{6}{*}{$\begin{array}{l}136 \mathrm{mg} \\
(10 \lambda)\end{array}$} & Mean pre-loading thresholds \pm SD & $10 \pm 2.2 \mathrm{~dB}$ & $10 \pm 1.52 \mathrm{~dB}$ & $10 \pm 3.5 \mathrm{~dB}$ & $12 \pm 2.5 \mathrm{~dB}$ & $11 \pm 3.85 \mathrm{~dB}$ & $10 \pm 3.98 \mathrm{~dB}$ & $12 \pm 4.96 \mathrm{~dB}$ & $10 \pm 3.58 \mathrm{~dB}$ \\
\hline & Mean post loading threshold \pm SD & $10 \pm 3.58 \mathrm{~dB}$ & $12 \pm 2.15 \mathrm{~dB}$ & $10 \pm 2.56 \mathrm{~dB}$ & $14 \pm 2.36 \mathrm{~dB}$ & $10 \pm 2.86 \mathrm{~dB}$ & $10 \pm 3.58 \mathrm{~dB}$ & $13 \pm 3.5 \mathrm{~dB}$ & $11 \pm 2.52 \mathrm{~dB}$ \\
\hline & Mean difference \pm SD & $0 \pm 0.36 \mathrm{~dB}$ & $1 \pm 0.58 \mathrm{~dB}$ & $0 \pm 0.98 \mathrm{~dB}$ & $1 \pm 1.36 \mathrm{~dB}$ & $2 \pm 0.25 \mathrm{~dB}$ & $0 \pm 0.89 \mathrm{~dB}$ & $1 \pm 1.89 \mathrm{~dB}$ & $1 \pm 0.36 \mathrm{~dB}$ \\
\hline & $95 \% \mathrm{Cl}$ & \pm 2.51561 & \pm 2.57634 & \pm 2.5960 & $\begin{array}{c}-4.0582 \mathrm{~dB} \text { to } \\
0.0582 \mathrm{~dB}\end{array}$ & $\begin{array}{c}-1.87128 \text { to } \\
3.87128\end{array}$ & \pm 3.20483 & $\begin{array}{c}-4.63429 \\
\text { to } 2.63429\end{array}$ & $\begin{array}{c}-3.62100 \text { to } \\
1.62100\end{array}$ \\
\hline & Standard error of difference & $1.213 \mathrm{~dB}$ & $0.760 \mathrm{~dB}$ & $1.252 \mathrm{~dB}$ & $0.992 \mathrm{~dB}$ & $1.385 \mathrm{~dB}$ & $1.545 \mathrm{~dB}$ & $1.752 \mathrm{~dB}$ & $1.264 \mathrm{~dB}$ \\
\hline & two-tailed $P$ value & 1.0000 & 0.2018 & 1.0000 & 0.0563 & 0.4777 & 1.0000 & 0.5740 & 0.4372 \\
\hline
\end{tabular}

Table II. Changes in hearing thresholds at $272 \mathrm{mg}$.

\begin{tabular}{|c|c|c|c|c|c|c|c|c|c|}
\hline \multirow{2}{*}{$\begin{array}{l}\text { Loads } \\
\text { Step } 2\end{array}$} & & \multicolumn{4}{|c|}{ Changes of air conduction hearing thresholds } & \multicolumn{4}{|c|}{ Changes of bone conduction hearing thresholds } \\
\hline & & $500 \mathrm{~Hz}$ & $1000 \mathrm{~Hz}$ & $2000 \mathrm{~Hz}$ & $4000 \mathrm{~Hz}$ & $500 \mathrm{~Hz}$ & $1000 \mathrm{~Hz}$ & $2000 \mathrm{~Hz}$ & $4000 \mathrm{~Hz}$ \\
\hline \multirow{6}{*}{$\begin{array}{l}272 \mathrm{mg} \\
(20 \lambda)\end{array}$} & Pre-loading thresholds \pm SD & $10 \pm 3.65 \mathrm{~dB}$ & $12 \pm 2.36 \mathrm{~dB}$ & $10 \pm 3.78 \mathrm{~dB}$ & $10 \pm 2.87 \mathrm{~dB}$ & $10 \pm 2.36 \mathrm{~dB}$ & $14 \pm 2.69 \mathrm{~dB}$ & $12 \pm 3.5 \mathrm{~dB}$ & $10 \pm 1.25 \mathrm{~dB}$ \\
\hline & Post-loading threshold \pm SD & $10 \pm 3.25 \mathrm{~dB}$ & $11 \pm 3.25 \mathrm{~dB}$ & $11 \pm 2.63 \mathrm{~dB}$ & $10 \pm 4.52 \mathrm{~dB}$ & $11 \pm 3.25 \mathrm{~dB}$ & $12 \pm 3.58 \mathrm{~dB}$ & $12 \pm 2.85 \mathrm{~dB}$ & $10 \pm 2.87 \mathrm{~dB}$ \\
\hline & Mean difference \pm SD & $0 \pm 0.63 \mathrm{~dB}$ & $1 \pm 0.97 \mathrm{~dB}$ & $1 \pm 0.12 \mathrm{~dB}$ & $0 \pm 0.36$ & $1 \pm 0.58 \mathrm{~dB}$ & $2 \pm 1.85 \mathrm{~dB}$ & $0 \pm 0.36 \mathrm{~dB}$ & $0 \pm 0.89 \mathrm{~dB}$ \\
\hline & $95 \% \mathrm{Cl}$ & \pm 2.92586 & $\begin{array}{c}-1.40457 \text { to } \\
3.40457\end{array}$ & $\begin{array}{c}-3.75685 \text { to } \\
1.75685\end{array}$ & \pm 2.71902 & $\begin{array}{c}-3.40457 \text { to } \\
1.40457\end{array}$ & $\begin{array}{c}-0.68087 \text { to } \\
4.68087\end{array}$ & \pm 2.70218 & \pm 1.87409 \\
\hline & Standard error of difference & $1.411 \mathrm{~dB}$ & $1.159 \mathrm{~dB}$ & $1.329 \mathrm{~dB}$ & $1.311 \mathrm{~dB}$ & 1.159 & 1.293 & 1.303 & 0.904 \\
\hline & two-tailed $\mathrm{P}$ value & 1.0000 & 0.3977 & 0.4599 & 1.0000 & 0.3977 & 0.1361 & 1.0000 & 1.0000 \\
\hline
\end{tabular}




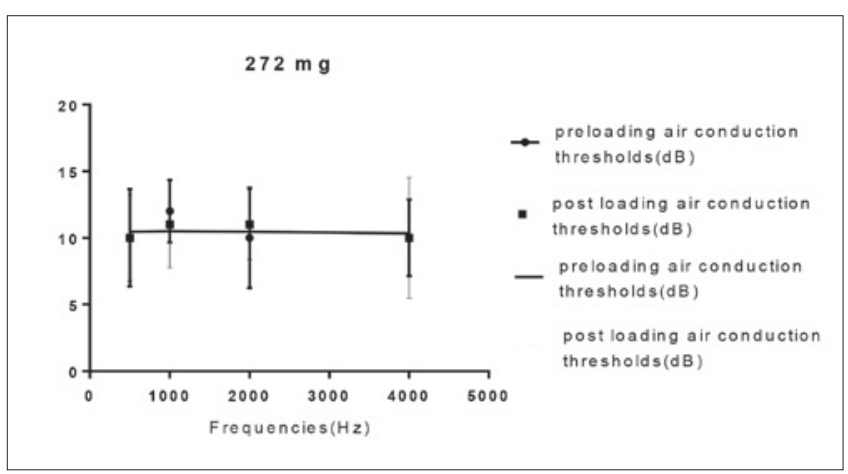

Fig. 3. Changes in air conduction hearing thresholds at $272 \mathrm{mg}$.

to previous bone conduction results, there was no significant effect.

\section{Discussion}

This topic is one of the least discussed issues in the literature despite its great relevance. Its importance can be observed by the fact that the greater the understanding of TM biomechanics, the greater the potential to monitor future advances in medical technology related to its surgical repair (myringoplasty) ${ }^{7}$.

There are only a very limited number of studies in the literature about this issue, which also involved animal experiments cats, dogs, rats and guinea pig ${ }^{6}$. Lüscher E. (1945) concluded that pointwise loading of the umbo or the manubrium in cats causes predominantly deafness towards low frequencies, whereas surface loading (covering) of the pars tensa, principally, causes deafness towards high frequencies ${ }^{4}$.

According to repeated results of our study, the human hearing system is resistant to pointwise mass loading except at very large masses ( $340 \mathrm{mg} ; 25 \lambda$ ). This mass is very large compared to the mean weight of the ossicles and the TM; the mean weights of human ossicles are $23 \mathrm{mg}$ for the malleus, $27 \mathrm{mg}$ for the incus and $4 \mathrm{mg}$ for the stapes; the average weight of the TM is $14 \mathrm{mg}^{8}$. It is also larger than the mean weight of the cartilage graft, which is $20 \pm 4.36 \mathrm{mg}$ according to our experiments ${ }^{5}$.

Masses from $13.6 \mathrm{mg}(\lambda)$ to $272 \mathrm{mg}(20 \lambda)$ did not have any significant impact on air or bone conduction hearing thresholds. The only significant effect was seen when the TM had a load of $340 \mathrm{mg}$. The air conduction hearing thresholds at $500 \mathrm{~Hz}, 1000 \mathrm{~Hz}$ and $2000 \mathrm{~Hz}$ increased by $10 \pm 3.69 \mathrm{~dB}, 10 \pm 2.35 \mathrm{~dB}$, and $10 \pm 3.55 \mathrm{~dB}$, respectively, without any evident effect at the frequency of $4000 \mathrm{~Hz}$.

When the TM had a load of $408 \mathrm{mg}(30 \lambda)$, the air con-

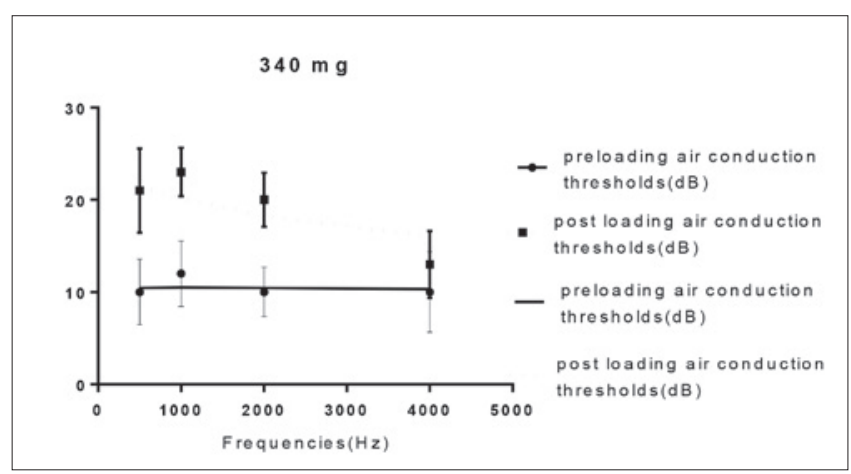

Fig. 4. Changes in air conduction hearing thresholds at $340 \mathrm{mg}$.

duction hearing threshold was increased by $17 \pm 3.38 \mathrm{~dB}$ at $500 \mathrm{~Hz}$. This effect decreased towards higher frequencies: at $1000 \mathrm{~Hz}$ air conduction hearing threshold increased by $16 \pm 4.87 \mathrm{~dB}$ and at $2000 \mathrm{~Hz}$ it increased by $10 \pm 2.60 \mathrm{~dB}$, but there was no effect at $4000 \mathrm{~Hz}$ which was affected only when the TM had plates of $476 \mathrm{mg}$ $(35 \lambda)$ and $544 \mathrm{mg}(40 \lambda)$. At $544 \mathrm{mg}(40 \lambda)$, the mean air conduction hearing loss was $10 \pm 3.98 \mathrm{~dB}$ at $(4000 \mathrm{~Hz})$. However, several experiments revealed an increase in bone conduction responses at low frequencies accompanied by a decrease at high frequencies and both of these changes, which is consistent in some proportion to the applied load ${ }^{9}$. In our study, there was no statistically significant difference in bone conduction hearing thresholds.

These results demonstrates why a heavy and stiff cartilage graft does not affect hearing results and changes some concepts regarding the mechanics of hearing loss in middle ear effusion; it is evident in the literature that the mass of fluid on the TM may reduce middle-ear input admittance ${ }^{10}$; however, the actual effect of the mass of effusion is minor according to our pointwise loading experiments.

\section{Conclusions}

The hearing system is very resistant to mass loading except at very large weights $(340 \mathrm{mg})$. Loading of the TM by different masses affects the air conduction hearing thresholds, especially low frequencies, but does not affect bone conduction hearing. Thus, it is now very clear why hearing results of the heavy and light grafts are statistically non-significant. Lastly, there is an obvious practical and experimental demonstration that the mass of the effusion of the middle ear does not have any role in hearing loss. 
Table III. Changes in hearing thresholds at $340 \mathrm{mg}$.

\begin{tabular}{|c|c|c|c|c|c|c|c|c|c|}
\hline \multirow{2}{*}{$\begin{array}{l}\text { Loads } \\
\text { Step } 2\end{array}$} & & \multicolumn{4}{|c|}{ Changes in air conduction hearing thresholds } & \multicolumn{4}{|c|}{ Changes of bone conduction hearing thresholds } \\
\hline & & $500 \mathrm{~Hz}$ & $1000 \mathrm{~Hz}$ & $2000 \mathrm{~Hz}$ & $4000 \mathrm{~Hz}$ & $500 \mathrm{~Hz}$ & $1000 \mathrm{~Hz}$ & $2000 \mathrm{~Hz}$ & $4000 \mathrm{~Hz}$ \\
\hline \multirow{6}{*}{$\begin{array}{l}340 \mathrm{mg} \\
(25 \lambda)\end{array}$} & Pre-loading thresholds \pm SD & $10 \pm 3.56 \mathrm{~dB}$ & $12 \pm 3.56 \mathrm{~dB}$ & $10 \pm 2.69 \mathrm{~dB}$ & $10 \pm 4.36 \mathrm{~dB}$ & $13 \pm 3.69 \mathrm{~dB}$ & $10 \pm 5.36 \mathrm{~dB}$ & $14 \pm 2.65 \mathrm{~dB}$ & $12 \pm 3.35 \mathrm{~dB}$ \\
\hline & Post-loading threshold \pm SD & $21 \pm 4.56 \mathrm{~dB}$ & $23 \pm 2.63 \mathrm{~dB}$ & $20 \pm 2.95 \mathrm{~dB}$ & $13 \pm 3.65 \mathrm{~dB}$ & $14 \pm 2.31 \mathrm{~dB}$ & $12 \pm 2.46 \mathrm{~dB}$ & $13 \pm 2.36 \mathrm{~dB}$ & $12 \pm 2.84 \mathrm{~dB}$ \\
\hline & Mean difference \pm SD & $\begin{array}{c}10 \pm 2.35 \\
\mathrm{dBHL}\end{array}$ & $\begin{array}{c}10 \pm 4.45 \\
\mathrm{dBHL}\end{array}$ & $\begin{array}{c}10 \pm 2.18 \\
\mathrm{dBHL}\end{array}$ & $\begin{array}{c}4 \pm 2.36 \\
d B H L\end{array}$ & $\begin{array}{c}0 \pm .25 \\
\mathrm{dBHL}\end{array}$ & $\begin{array}{c}2 \pm .85 \\
\mathrm{dBHL}\end{array}$ & $\begin{array}{c}1 \pm 1.63 \\
\mathrm{dBHL}\end{array}$ & $\begin{array}{c}0 \pm 0.21 \\
\mathrm{dBHL}\end{array}$ \\
\hline & $95 \% \mathrm{Cl}$ of difference & $\begin{array}{c}-13.36981 \text { to } \\
-6.63019\end{array}$ & $\begin{array}{c}-13.64981 \text { to } \\
-8.35019\end{array}$ & $\begin{array}{c}-12.39010 \text { to } \\
-7.60990\end{array}$ & $\begin{array}{c}-6.40415 \text { to } \\
0.40415\end{array}$ & $\begin{array}{c}-3.6063 \text { to } \\
1.6063\end{array}$ & $\begin{array}{c}-5.53072 \text { to } \\
1.53072\end{array}$ & $\begin{array}{c}-1.12442 \text { to } \\
3.12442\end{array}$ & \pm 2.62928 \\
\hline & Standard error of difference & 1.625 & 1.278 & 1.152 & 1.641 & 1.257 & 1.702 & 1.024 & 1.268 \\
\hline & two-tailed $\mathrm{P}$ value & $<0.0001^{*}$ & $<0.0001^{*}$ & $<0.0001^{*}$ & 0.0812 & 0.4347 & 0.2527 & 0.3396 & 1.0000 \\
\hline
\end{tabular}

Table IV. Changes in hearing thresholds at $408 \mathrm{mg}$.

\begin{tabular}{|c|c|c|c|c|c|c|c|c|c|}
\hline \multirow{2}{*}{$\begin{array}{l}\text { Loads } \\
\text { Step } 2\end{array}$} & & \multicolumn{4}{|c|}{ Changes in air conduction hearing thresholds } & \multicolumn{4}{|c|}{ Changes of bone conduction hearing thresholds } \\
\hline & & $500 \mathrm{~Hz}$ & $1000 \mathrm{~Hz}$ & $2000 \mathrm{~Hz}$ & $4000 \mathrm{~Hz}$ & $500 \mathrm{~Hz}$ & $1000 \mathrm{~Hz}$ & $2000 \mathrm{~Hz}$ & $4000 \mathrm{~Hz}$ \\
\hline \multirow{6}{*}{$\begin{array}{l}408 \mathrm{mg} \\
(30 \lambda)\end{array}$} & Pre-loading thresholds \pm SD & $10 \pm 2.35 \mathrm{~dB}$ & $12 \pm 3.56 \mathrm{~dB}$ & $14 \pm 4.36 \mathrm{~dB}$ & $14 \pm 2.56 \mathrm{~dB}$ & $10 \pm 2.36 \mathrm{~dB}$ & $10 \pm 3.56 \mathrm{~dB}$ & $12 \pm 2.47 \mathrm{~dB}$ & $11 \pm 3.25 \mathrm{~dB}$ \\
\hline & Post-loading threshold \pm SD & $27 \pm 2.36 \mathrm{~dB}$ & $28 \pm 3.56 \mathrm{~dB}$ & $24 \pm 2.36 \mathrm{~dB}$ & $16 \pm 2.36 \mathrm{~dB}$ & $10 \pm 3.65 \mathrm{~dB}$ & $12 \pm 3.26 \mathrm{~dB}$ & $10 \pm 4.35 \mathrm{~dB}$ & $10 \pm 3.89 \mathrm{~dB}$ \\
\hline & Mean difference \pm SD & $\begin{array}{c}17 \pm 3.38 \\
\mathrm{~dB} \mathrm{HL}\end{array}$ & $\begin{array}{c}16 \pm 4.87 \\
\mathrm{dBHL}\end{array}$ & $\begin{array}{c}10 \pm 2.60 \\
\mathrm{dBHL}\end{array}$ & $\begin{array}{c}2 \pm 1.56 \\
\mathrm{dBHL}\end{array}$ & $\begin{array}{c}0 \pm 0.25 \\
\mathrm{dBHL}\end{array}$ & $\begin{array}{c}0 \pm .59 \\
\mathrm{dBHL}\end{array}$ & $\begin{array}{c}2 \pm 1.36 \\
\mathrm{dBHL}\end{array}$ & $\begin{array}{c}1 \pm 0.29 \\
\mathrm{dBHL}\end{array}$ \\
\hline & $95 \% \mathrm{Cl}$ of difference & $\begin{array}{c}-18.99388 \text { to } \\
-15.00612\end{array}$ & $\begin{array}{c}-19.0141 \text { to } \\
-12.9859\end{array}$ & $\begin{array}{c}-12.96808 \text { to } \\
-7.03192\end{array}$ & $\begin{array}{c}-4.08449 \text { to } \\
0.08449\end{array}$ & \pm 2.60215 & $\begin{array}{c}-4.88989 \text { to } \\
0.88989\end{array}$ & $\begin{array}{c}-0.99478 \text { to } \\
4.99478\end{array}$ & $\begin{array}{c}-2.03468 \text { to } \\
4.03468\end{array}$ \\
\hline & Standard error of difference & 0.961 & 1.453 & 1.431 & 1.005 & 1.255 & 1.393 & 1.444 & 1.463 \\
\hline & two-tailed $\mathrm{P}$ value & $<0.0001^{\star}$ & $<0.0001^{*}$ & $<0.0001^{*}$ & 0.0592 & 1.0000 & 0.1653 & 0.1799 & 0.5015 \\
\hline
\end{tabular}

Table V. Changes in hearing thresholds at $544 \mathrm{mg}$.

\begin{tabular}{|c|c|c|c|c|c|c|c|c|c|}
\hline \multirow{2}{*}{$\begin{array}{l}\text { Loads } \\
\text { Step } 2\end{array}$} & & \multicolumn{4}{|c|}{ Changes in air conduction hearing thresholds } & \multicolumn{4}{|c|}{ Changes of bone conduction hearing thresholds } \\
\hline & & $500 \mathrm{~Hz}$ & $1000 \mathrm{~Hz}$ & $2000 \mathrm{~Hz}$ & $4000 \mathrm{~Hz}$ & $500 \mathrm{~Hz}$ & $1000 \mathrm{~Hz}$ & $2000 \mathrm{~Hz}$ & $4000 \mathrm{~Hz}$ \\
\hline \multirow{6}{*}{$\begin{array}{l}544 \mathrm{mg} \\
(40 \lambda)\end{array}$} & Mean pre-loading thresholds \pm SD & $10 \pm 3.25 \mathrm{~dB}$ & $10 \pm 2.89 \mathrm{~dB}$ & $13 \pm 5.85 \mathrm{~dB}$ & $10 \pm 5.85 \mathrm{~dB}$ & $12 \pm 3.36 \mathrm{~dB}$ & $10 \pm 1.56 \mathrm{~dB}$ & $10 \pm 2.47 \mathrm{~dB}$ & $13 \pm 2.25 \mathrm{~dB}$ \\
\hline & Mean post-loading threshold \pm SD & $30 \pm 3.25 \mathrm{~dB}$ & $25 \pm 3.65 \mathrm{~dB}$ & $24 \pm 3.69 \mathrm{~dB}$ & $20 \pm 2.36 \mathrm{~dB}$ & $11 \pm 3.21 \mathrm{~dB}$ & $10 \pm 3.24 \mathrm{~dB}$ & $12 \pm 4.25 \mathrm{~dB}$ & $\begin{array}{c}12 \pm \\
2.89 \mathrm{~dB}\end{array}$ \\
\hline & Mean difference \pm SD & $\begin{array}{c}20 \pm 3.44 \\
\mathrm{dBHL}\end{array}$ & $\begin{array}{c}14 \pm 5.67 \\
\mathrm{dBHL}\end{array}$ & $\begin{array}{c}10 \pm \\
3.58 \mathrm{dBHL}\end{array}$ & $\begin{array}{c}10 \pm 3.98 \\
\mathrm{dBHL}\end{array}$ & $\begin{array}{c}1 \pm 0.25 \\
\mathrm{dBHL}\end{array}$ & $0 \pm .89 \mathrm{dBHL}$ & $1 \pm 1.36 \mathrm{dBHL}$ & $1 \pm 0.99 \mathrm{dBHL}$ \\
\hline & $95 \% \mathrm{Cl}$ & $\begin{array}{c}-22.86821 \text { to } \\
-17.13179\end{array}$ & $\begin{array}{c}-17.78719 \text { to } \\
-12.21281\end{array}$ & $\begin{array}{c}-14.14077 \text { to } \\
-5.85923\end{array}$ & $\begin{array}{c}-13.77650 \text { to } \\
-6.22350\end{array}$ & $\begin{array}{l}-1.78199 \text { to } \\
3.78199\end{array}$ & \pm 2.15284 & $\begin{array}{c}-4.94287 \text { to } \\
0.94287\end{array}$ & $\begin{array}{c}-1.19271 \text { to } \\
3.19271\end{array}$ \\
\hline & Standard error of difference & 1.383 & 1.344 & 1.997 & 1.821 & 1.341 & 1.038 & 1.419 & 1.057 \\
\hline & two-tailed $P$ value & $<0.0001^{*}$ & $<0.0001^{\star}$ & $<0.0001^{*}$ & $<0.0001^{*}$ & 0.4639 & 1.0000 & 0.1727 & 0.3545 \\
\hline
\end{tabular}

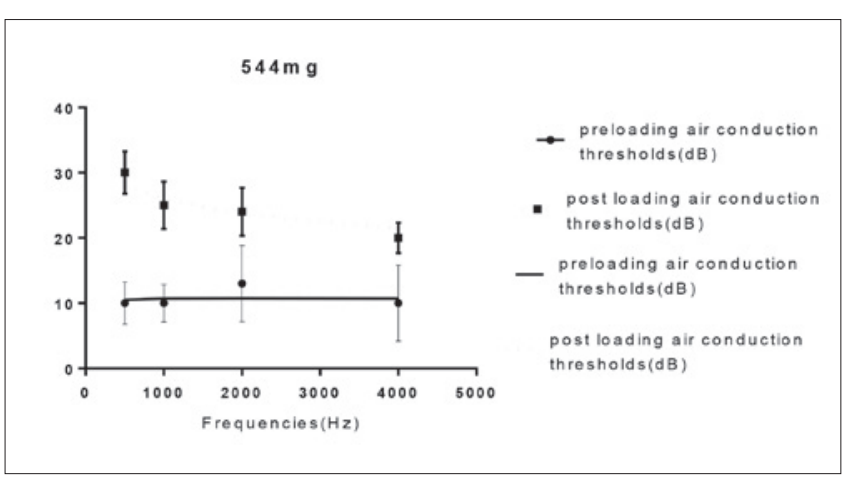

Fig. 5. Changes in air conduction hear at $544 \mathrm{mg}$.

\section{Acknowledgements}

The authors would like to thank the reviewers for their insights, Professors Mohamed Bassiony, Ph.D. and Hany Elgar, Ph.D. for their comments on an earlier version of the manuscript, although, many errors are our own and should not tarnish the reputation of these esteemed persons. I am also immensely grateful to my beloved wife for her great and continuous support and my patients who were the main source of data. This study is totally self-funded, I did not have any grants or financial support from any institute or company, and there is no financial interest or conflicts. I 
only work to produce a positive impact in the literature that could change some concepts in my specialty.

\section{References}

1 Furlong C, Rosowski JJ, Hulli N, et al. Preliminary analyses of tympanic-membrane motion from holographic measurements. Strain 2009;45:301-9.

2 Cheng JT, Aarnisalo AA, Harrington E, et al. Motion of the surface of the human tympanic membrane measured with stroboscopic holography. Hear Res 2010;263:66-77.

3 Cheng T, Dai C, Gan RZ. Viscoelastic properties of human tympanic membrane. Ann Biomed Eng 2007;35:305-14.

4 Lüscher E. The functional effect of loading of the tympanic membrane. Acta Otolaryngol 1945;33:265-72.

5 Abdalla MKTM. Effect of the weight of cartilage and fascia grafts on the audiological outcome of myringoplasty. Otorinolaringol 2016;66:49-53.
6 Tonndorf J. Animal experiments in bone conduction: clinical conclusions. Trans Am Otol Soc 1964;52:22-43.

7 Jackson RP, Chlebicki C, Krasieva TB, et al. Multiphoton microscopy imaging of collagen fiber layers and orientation in the tympanic membrane. In: Biomedical Optics (BiOS). International Society for Optics and Photonics; 2008. p. 68421D-68421D.

8 Adams JC, Liberman MC. Anatomy. In Merchant, SN, Nadol JB, editors. Schuknecht's Pathology of the Ear. PMPH-USA; 2010.

9 Tonndorf J. Bone conduction. Studies in experimental animals. Acta Otolaryngol 1966;Suppl 213:1.

10 Ravicz ME, Rosowski JJ, Merchant SN. Mechanisms of hearing loss resulting from middle-ear fluid. Hear Res 2004;195:103-30.

Received: October 6, 2016 - Accepted: June 23, 2017

Address for correspondence: Mohamed Khamis Tolba Mahmoud Abdalla, Department of Otorhinolaryngology, Head and Neck Surgery, Alexandria University, Alexandria, Egypt. Tel.+021003052995. E-mail: Mohamed_khameess@yahoo.com 